\title{
Economic Growth : The Impact of Zakat Funds and Tax on Business Capital
}

\author{
Sri Dewi Anggadini ${ }^{1}$, Surtikanti², Faez M. Hassan ${ }^{3}$
}

Accounting Department, Universitas Komputer Indonesia ${ }^{\mathrm{I}, 2}$

Physics Department, College of Education Mustansiriyah University, Baghdad, $\operatorname{Iraq}^{3}$ dewianggadini8@gmail.com ${ }^{I}$,kanti haidar@yahoo.com², faizmohammed2007@gmail.com ${ }^{3}$

\begin{abstract}
This study aims to determine the influence of Zakat Funds and Tax on Business Capital on Economic Growth. The population in this study is data from West Java Province from 2010 to 2017 which uses reports on economic growth, Tax on Business Capital and reports on zakat funds distribution. The sample taken by the author in this study is Zakat Fund Distribution Data, Regional Data and West Java Province Gross Regional Domestic Product (PDRB) Data from 2010 to 2017. The research method used is multiple regression with a correlation approach. To get more accurate results in multiple regression analysis, the classical assumption is tested so that the results obtained are in the form of a regression equation. The results show that the data on Zakat Funds Distribution and Tax on Business Capital have a significant effect on economic growth, meaning that the increasing the amount of zakat funds and Tax on Business Capital, the more economic growth will increase. It is hoped that this research can contribute to the next research that discusses economic growth.
\end{abstract}

Keywords : Zakat Funds, Tax on Business Capital, Economic Growth

\section{A. INTRODUCTION}

Economic growth is a central theme in the economic life of all countries in the world today. A good rate of economic growth is seen as one of the successful achievements of development in these countries. Whether the quality of government policy is bad or high or low quality of the apparatus in the economy omit is also usually measured by the speed of growth of the national output produced. (Kharina Tambunan, 2016). Economic growth, according to Islamic economics is not just related to the increase in goods and

Received : September I0,2020 - Revised: November 09,2020 - Accepted: November 26,2020

Occupuation: Accounting Department, Universitas Komputer Indonesia ${ }^{\mathrm{I}, 2}$

College of Education Mustansiriyah University, Baghdad, Iraq ${ }^{3}$

E-mail : dewianggadini8@gmail.com ${ }^{\mathrm{I}}$,

kanti_haidar@yahoo.com ${ }^{2}$,faizmohammed2007@,gmail.com ${ }^{3}$ 
services, but also related to aspects of morality and moral quality and the balance between worldly and ukhrawi goals (B. Gashi, G. Asllani, 2018). For the success of economic growth is not only seen in terms of material achievements or the results of the quantity, but also in terms of improving religious, social and social life. If the economic growth that occurs precisely triggers backwardness, chaos, and far from the values of justice and humanity, then certainly the growth is not under the Islamic economy. (Beik, 20I6).

In Islamic economics perspective, there are also many factors that influence economic growth, namely the distribution of ZIS funds (Zakat, Infaq, Sadaqah). Zakat in the form of consumptive assistance provided to mustahik will increase the income of mustahik, which means that the purchasing power of mustahik for a product that becomes its needs will also increase. Increased purchasing power of a product will have an impact on increasing demand for a product (Patmawati Ibrahim, Mazliana Muridan, 2020). The increase in demand must still pay attention to Islamic principles so that it does not deviate from Sharia provisions. An increase in demand means an increase in a company's production, the impact of an increase in production is the addition of production capacity, which means the company will absorb more labor. From this explanation, it is explained that zakat can produce a multiplier effect in the economy. Zakat funds in the form of consumptive assistance alone are able to give a significant multiplier effect, especially as zakat is provided in the form of productive assistance such as working capital or revolving funds, then what is obtained will be greater in an economy (Joko Tri Haryanto, 2017). According to Sadono Sukirno (2008: 429) Political stability, government economic policies, natural resources owned, the number and ability of workers, the availability of persistent entrepreneurs and the ability to develop and use technology are some important factors that influence economic growth. Some factors that have long been seen by economists as an important source of realizing economic growth are as follows: I) Land and other natural resources. 2) Number and quality of population and labor. 3) Capital goods and technological level. 4) Social systems and community attitudes.

Tax reform in Indonesia began with the issuance of Law No. 6 of 1983 dated December 3I, 1983 concerning General Provisions and Tax Procedures. One of the aims of tax reform is to make an effectual and efficient taxation system so that state revenue from tax income can increase significantly. Substantial growth in tax revenue will affect Indonesia's 
economic growth because the revenue can be used to run the country, including development in several lines with the ultimate goal of creating prosperity for the people of Indonesia. In the context of implementing regional autonomy, the regions are demanded to further enhance the financial independence of their regions in order to be able to carry out and finance their regional household affairs (Roshaiza Taha, Loganathan, 2019). For this reason, regions need to explore sufficient sources of taxes and user charges in carrying out government and development affairs. (Defia Riski Anggarini, 2018). If tax revenue is used to fund productive activities or projects, it will have a positive impact on the economic growth of a region or country. (Arfah Habib Saragih, 2018). According to finance minister, the results of Bank Indonesia (BI) calculations indicate that economic growth in the first quarter of 2019 is expected to grow by $5.13 \%$, or an increase of $0.07 \%$ compared to the same quarter of 20I8, which is $5.06 \%$. This economic growth is also expected to increase in the next quarters. Still, in the first quarter of 2012 tax revenues reached $\operatorname{Rp} 248.98$ trillion or $15.78 \%$ of the target. This achievement was lower than the same quarter in 2018, which was $17.17 \%$ of the target. On one hand economic growth has increased, but tax revenues have actually rejected. This explains that a decrease in tax revenue, while at the same time economic growth increased. This is not in line with the theory that tax revenue should take in a positive effect on economic growth (Serhat Yüksel, 2017).

Based on data that the amount of zakat funds distribution in West Java Province has increased continuously, while economic growth in 20II, 2013, 2014, 2015 and 2017 has decreased. This is not in accordance with the theory that zakat can be employed to control and encourage economic growth. (Ryandono, 2008: 53) which means that if zakat increases, then economic growth will be encouraged to receive an increase. Furthermore, data related to the amount of Tax on Business Capital revenue in West Java Province in 20II, 20I4, 2015 and 2017 experienced an increase, while economic growth in that year experienced a decline. This is not in accordance with the theory that tax revenue on economic growth indicates that increasing tax revenue tends to be followed by increasing the rate of economic growth (Ayu Yudiawati, 2013). This research is different from previous research according to (Adel Sarea, 2012) and (Elleriz Aisha Khasandy \& Rudy Badrudin, 2019), namely the model used in this study uses more varied 
indicators so that the factors that have an impact on economic growth are seen from the indicators of each variable.

\section{B. THEORITICAL}

Distribution is circulation / dissemination / delivery of goods and so on to many people or places. (Meity Taqdir Qadratillah, 20II: I00) Etymologically zakat has several meanings, namely developing, a blessing and a lot of goodness. It's called because if the property is issued, the wealth will grow and bless and be better. (Mardani., 2016). According to (Sri Dewi Anggadini dan Adeh Ratna Komala, 2017), zakat is a treasure that must be issued by muzakki in accordance with sharia provisions to be given to those entitled to receive it (mustahiq) (Petar Chobanov, 2019). Zakat is a Shari'a obligation which must be submitted by muzakki to mustahiq either through amil or directly. The provisions of zakat govern the requirements of Nisab, haul (both periodic and non-periodic) zakat rates (qadar) and their designation (Ummu Salma Al Azizah and Muhammad Choirin, 2018).

Mustahiq from the word haqqa yahiqu hiqqan wa hiqqotan means the truth of rights and necessity. Mustahiq isim fail from istihaqqa yastahiqqu, istihaq, meaning to have the right or to claim rights. Mustahiq zakat is a group of people who are entitled to receive zakat that has been determined in the Qur'an. Mustahiq can be in the form of individuals or institutions. According to (Sapiudinn Shidiq, 2016) eight groups of zakat mustahiq are: I) Fuqara, namely people who do not have property and jobs that can meet their daily needs. People who belong to this group are those who do not have a husband (wife), father, mother and children who can meet their daily needs. 2) Masakin, namely people who have jobs, but the results cannot meet their needs. 3) Amil, namely people who work to collect zakat (zakat committee). 4) Converts, which can mean people who have just converted to Islam while their faith is still weak, so to strengthen it needs to be convinced with zakat. 5) Slaves, namely people whose lives are not free, are controlled by their lords. 6) People who are in debt, that is, people who have arrears of debt to other people, whether the debt is for personal gain or debt for the cost of piety.

7) Those who fight in the path of Allah, namely the soldiers who fight against the infidels.

8) People who are traveling, that is, people who are traveling with a good purpose not for disobedience, such as students studying abroad. 
Zakat management indicators according to Mardani (2016:13) that the compliance of zakat institutions to the provisions of the law is one indicator of the success of the development of zakat management systems. Therefore, the legality of amil zakat institutions is important to be obtained. In addition, the increase in the collection of zakat and the distribution of zakat to those entitled to receive is also one of the determining factors w (Wan Sulaiman bin Wan Yusoff, 2008). The third indicator of the successful development of the zakat management system is the increase in output (output) of poverty alleviation through zakat funds and the fourth is, strengthening strategic partnerships among all zakat stakeholders at the central and regional levels (Keumala Hayati and Indra Caniago, 20I I).

Taxes according to the collecting agency are divided into Central Tax and Tax on Business Capital. The Central Tax is a tax collected by the central government and is used to finance state households. (Abdul Halim, 2016). Local tax according to the Law of the Republic of Indonesia number 28 of 2009 concerning Tax on Business Capitales and Regional Regulations, the definition of local tax is Tax on Business Capital, hereinafter referred to as Tax, is a mandatory contribution to the Region owed by individuals or compelling entities based on the Law, by not getting a direct reward and used for the needs of the Region for the maximum prosperity of the people.

According to (Rahmad, T Zulham, 2019), based on one of the functions of the tax is the budgetary function which is the principal function of the tax, or the fiscal function (fiscal function), which is the tax used as a tool to optimize place funds into the state treasury carried out by the system collection based on applicable tax laws. According to (Ayu Yudiawati, 2013) that to ensure optimal tax revenue, it can be determined from the realization of tax revenues in certain points. Based on the sources stated above, the tax revenue indicator used in this study is an indicator using the amount of tax revenue earned.

Economic growth is a significant gain in national income (with increasing per capita income) in a certain calculation period. (Iskandar Putong, 2015) Economic growth can be defined as the development of economic activities that cause the goods and services made in society to increase. (Sadono Sukirno, 2008: 9). It can be supposed that economic growth is the process of increasing the production an economic system, manifested in an increase in national income within a certain calculation 
period. Economic growth links and calculates the level of national income from one period to the next (Eko Suprayitno, 2018).

The regional concept of Gross Domestic Product is known as Gross Regional Domestic Product (Ioan Dan Morar, 2015). Basically, it is the amount of added value generated by all business units in a certain area (Hanny Dzikria Sahlina, 2018). Based on the sources stated above, the economic growth indicator used in this study is an indicator of the realization of the Gross Regional Domestic Product (PRDB).

According to Skousen in (Rachmasari Anggraini, 2016) ZIS contributes to economic growth both through the aggregate revenue channel and the aggregate supply channel. The positive impact of ZIS on consumption and investment will clearly increase aggregate demand in the economy. The results of the study stated that ZIS had a positive and significant effect on economic growth in Indonesia (Rachmasari Anggraini, 2016). According to Ryandono (2008: 53) Islam forbids Muslims from hoarding wealth and leaving it unproductive. Wealth must always spin so that more benefits for their own owners, for other people and the environment, so that property does not only revolve among rich people. Zakat which is required in Islam has a function, one of which is as an instrument to encourage and can even be used to force someone to make their assets to be always productive. On the other hand the zakat will make the economy go round. With the rotation of assets in the economy, it will increase output (economic development and growth), employment, income and community welfare. In other words zakat can be used to control and encourage economic growth (Arif Orçun Söylemez, 2017).

The influence of tax according to (Waluyo, 20I4) From an economic point of view, tax is a state revenue that is used to guide people's lives towards prosperity because tax as a motor of community economic life that is run by the government to provide various economic infrastructure that supports the economy and is closely connected to economic growth. The influence of the independent variable, namely local tax revenue on the dependent variable, namely economic growth, which has a significant effect. Tax on Business Capitales have a significant influence on Economic Growth (Hesti Handiani, 2015).

Based on the theoretical framework above, the authors assume a temporary decision (hypothesis) is as follows:

HI: Zakat Fund Distribution has an effect on Economic Growth. 
H2: Local Tax Revenue affects Economic Growth.

\section{METHODOLOGY}

Research is mostly defined as a process of collecting and analyzing data that is carried out systematically and logically to reach certain goals. Research is a systematic process for solving problems. Research is searching or researching again. Systematic means that there are certain procedures or steps. Minimum procedures for collecting, analyzing and interpreting and summarizing data. (Husaini Usman \& Purnomo Setiadi Akbar, 2017). The research method is a method or technique that can help researchers about the order in which the research is conducted. According to (Sugiyono, 2017) the research method is a scientific way to obtain data with specific purposes and uses. Meanwhile, according to (Danang Sunyoto, 2016), the research method will determine the sequence of data analysis processes that will be presented systematically. From this understanding it can be said that research methods are scientific ways and procedures that are designed systematically and organized to obtain data that is used to achieve certain goals and procedures for a study carried out. By using the research method will be known the significance of the relationship between the variables studied so that conclusions that will clarify the picture of the object under study.

In this study the methods applied in quantitative research are descriptive methods and verification methods with descriptive and verification approaches with quantitative approaches. The reason the researcher chose the descriptive and verification method was used to test the effect of the Distribution of Zakat Funds and Tax on Business Capitales on Economic Growth and to test the theory by proving a hypothesis whether it was assumed or declined. While the object of research in this study is the Distribution of Zakat Funds, Tax on Business Capitales and Economic Growth in West Java. The unit of analysis and the unit of observation become very important in a study. This relates to the place of research and the research section of the analysis unit. The unit of analysis in this study is the Economic Growth Rate of West Java Province.

According to (Sugiyono, 2017) explains the definition of data collection techniques is the most strategic step in research, because the main purpose of the research is to produce data. In this study, data collection techniques carried out by researchers are: I) Field Research. Field research is research conducted directly by the authority that is the object of research. The information obtained are secondary data obtained by collecting information. By 
entering data relating to the problem to be examined from documents related to the object of research. Based on this research, it is expected to obtain the required data. In this study, the authors take secondary data from the Zakat Outlook Amil Zakat Agency in West Java Province and from West Java on West Java Central Statistics Agency Numbers. 2) Literature Research. Data collection is performed by understanding the literature, books, legislation, newspapers, articles about the relationship with the problems examined in the search for additional information about the theory and the data needed in this study. 3) Internet Research. Data collection comes from related sites to obtain additional literature, journals and other data related to this research.

According to (Sugiyono, 2017), the notion of population is the area of generalization consisting of objects / subjects that have certain qualities and characteristics determined by researchers to be analyzed and then drawn the conclusions. The population in this study is the West Java Province Data for 2010 to 2017 where the economic growth report, Tax on Business Capital report and zakat fund distribution report are used. The sample is a part of the total number and characteristics possessed by the population. According to (Sugiyono, 2017) defines the sample is part of the figure and characteristics possessed by the population. The sample used in this study using purposive sampling technique. According to (Sugiyono, 2017), purposive sampling is a sampling technique with certain considerations. The consideration in this research is the availability of data for 8 years and the phenomenon that occurred in 20I I, 2013, 2014, 2015 and 2017. That way the data obtained by researchers are only 8 years. The sample taken by the author in this study is the data distribution of Zakat Funds, Tax on Business Capital data and the data of the Gross Regional Domestic Product (PDRB) of West Java Province from 2010 to 2017.

Methods of Testing the influence of Zakat Funds and Tax on Business Capital Distribution on Economic Growth in West Java Province from 2010 to 2017 can be investigated by several methods. Researchers used multiple statistical analysis and correlation methods. The calculation using the statistical method uses the Computer Statistical Program for Social Science (SPSS) program. To obtain more accurate results in multiple regression analysis, classic assumption testing is executed so that the results obtained are regression equations that have the Best Linear Unlimited Estimator (BLUE) properties. This is performed before testing the hypothesis. Some classic regression assumptions that must be met first before using multiple regression analysis 
(Multiple Linear Regression) as a tool to analyze the effect of the variables studied.

The analysis of multiple linear regression aims to explain the magnitude of the influence of Zakat Fund Distribution (XI) and Tax on Business Capital (X2) on Economic Growth (Y). To draw the area of acceptance or rejection, the following standards are used:

a. If a $\mathrm{t}$ arithmetic oval table, then $\mathrm{Ho}$ is in the rejection region, meaning $\mathrm{Ha}$ is accepted, it means that between variables XI, X2 and $Y$ variables have an effect;

b. If tcount $\leq$ ttable, then Ho is in the reception area, it means that $\mathrm{Ha}$ is rejected, which means that between variables XI, X2 and Y have no effect;

c. t count: search with the arithmetic calculation; and

d. $t$ table: look for in the $t$ student distribution table with the following conditions $\alpha=0.05$ and $\mathrm{df}=$ (number of data $/ \mathrm{n}-\mathrm{k}-\mathrm{I}$ ) or $8-2-\mathrm{I}=$ 5 .

The shaded area is a rejection area and applies vice versa. If $\mathrm{t}$ arithmetic falls in the region of rejection (acceptance) then Ho is rejected (accepted) and $\mathrm{Ha}$ is accepted (rejected). This implies that the regression coefficient is significant (not significant). The conclusion is the distribution of Zakat Funds and Tax on Business Capital Revenues affect (not affect) Economic Growth. The significance level is $5 \%(\alpha=0.05)$ meaning that if the null hypothesis is rejected (accepted) with a confidence level of $95 \%$, then it is probable that the results of drawing conclusions have a truth of $95 \%$ and this shows the existence (no convincing influence (significant) between these two variables). In this case it is indicated by Ho's refusal or alternative acceptance ( $\mathrm{Ha}$ ).

\section{RESULTS AND DISCUSSION}

The variables in this study are delineated, then to test whether there is an influence of the distribution of zakat funds and local taxes on economic growth, which includes studies in the field of murabahah. Murabahah is basically a trade transaction. The main basis for murabahah transactions is from Q.S. al-Baqarah (2] 275, which means "And Allah has made usury lawful and forbidden usury". Also in Q.S. An-Nisa (4): 29 that means, "O believers, do not eat of your wealth in a false way, except by the way of business that is in 
the same way as any of you. And do not kill yourselves; Verily Allah is merciful to you."

Statistical testing is performed using multiple regression analysis through the following stages: Classic assumption test, multiple linear regression analysis, correlation analysis, determination analysis, and hypothesis testing. The test was carried out with the help of SPSS software Version 24.0.

After the proposed regression model passes the classical assumption test, then the next multiple linear regression analysis can be done in order to test the hypothesis proposed in this study and determine the multiple linear regression equation. According to (Danang Sunyoto, 2016), the multiple linear regression equation in this study is formulated in the regression model as follows:

$$
\mathrm{Y}=\mathrm{b}_{0}+\mathrm{b}_{1} \mathrm{X}_{1}+\mathrm{b}_{2} \mathrm{X}_{2}
$$

Information :

$\mathrm{Y}=$ Economic growth

$\mathrm{XI}=$ Distribution of zakat funds

$\mathrm{X} 2=$ Tax on Business Capital

$\mathrm{bO}=$ Constant

$\mathrm{bI}, \mathrm{b} 2=$ Regression Coefficient

By using SPSS 24.0 software, the results of multiple linear regression analysis are obtained as follows:

Table I

Multiple Linear Regression Analysis Results

\begin{tabular}{|c|c|c|c|c|c|c|}
\hline \multicolumn{7}{|c|}{ Coefficients $^{a}$} \\
\hline & & \multicolumn{2}{|c|}{$\begin{array}{l}\text { Unstandardized } \\
\text { Coefficients }\end{array}$} & $\begin{array}{c}\text { Standar } \\
\text { dized } \\
\text { Coeffic } \\
\text { ients }\end{array}$ & \multirow[b]{2}{*}{$\mathrm{t}$} & \multirow[b]{2}{*}{ Sig. } \\
\hline \multicolumn{2}{|c|}{ Model } & B & Std. Error & Beta & & \\
\hline \multirow[t]{3}{*}{ I } & $\begin{array}{c}(\text { Con } \\
\text { stant } \\
)\end{array}$ & 3.328 & 0.128 & & 25.465 & 0.018 \\
\hline & XI & 0.215 & 0.359 & 0.239 & 3.599 & 0.575 \\
\hline & $\mathrm{X} 2$ & 0.739 & $0.37 \mathrm{I}$ & $0.18 \mathrm{I}$ & 3.727 & 0.042 \\
\hline
\end{tabular}


From the regression calculations that have been processed above, the linear regression equation is obtained as follows :

$$
Y=3,328+0,215 X_{1}+0,739 X_{2}
$$

The coefficients contained in the above equation can be explained as follows : $\mathrm{bI}=0.2 \mathrm{I} 5$ This means that if the distribution of Zakat Funds (XI) increases by I unit and the Tax on Business Capital variable (X2) is constant, then Economic Growth (Y) will increase by 0.2I5. Furthermore b2 $=0.739$ This means that if the Tax on Business Capital (X2) increases by I unit and the variable Distribution of Zakat Funds (XI) is constant, then Economic Growth (Y) will increase by 0.739. Determination Coefficient Analysis (KD) is used to see how much the independent variable $(\mathrm{X})$ influences the dependent variable (Y) expressed as a percentage (Danang Sunyoto, 2016).

The magnitude of the coefficient of determination is calculated using the following formula:

$$
\mathrm{Kd}=\mathrm{r}^{2} \times 100 \%
$$

The greater the value it shows that the resulting regression equation is good for estimating the dependent variable. Following are the results of the analysis of the determination coefficient in this study.

Table 2

Coefficient Determination Results

\begin{tabular}{|c|c|r|r|r|c|}
\hline \multicolumn{7}{|c|}{ Summary Model $^{\mathrm{b}}$} \\
\hline Model & $\mathrm{R}$ & $\begin{array}{c}\mathrm{R} \\
\text { Square }\end{array}$ & $\begin{array}{c}\text { Adjusted R } \\
\text { Square }\end{array}$ & $\begin{array}{c}\text { Std. Error of the } \\
\text { Estimate }\end{array}$ & $\begin{array}{c}\text { Durbin- } \\
\text { Watson }\end{array}$ \\
\hline I & $.886^{\mathrm{a}}$ & 0.760 & 0.698 & 0.37289 & 1.835 \\
\hline \multicolumn{7}{|c|}{ a. Predictors: (Constant), Zakat_X2 Fund Distribution, Tax on Business } \\
Capital_XI \\
\hline \multicolumn{7}{|c|}{ b. Dependent Variable: Economic Growth_Y } \\
\hline
\end{tabular}

Based on table 2 above, information is obtained that the R-square is 0.760 or $76 \%$. This value indicates that the distribution of zakat funds and local taxes simultaneously in giving effect to the variable economic growth of 
$76 \%$. While the rest of $100 \%-76 \%=$ another $24 \%$ is the influence of other variables not examined in this study.

Based on the results of hypothesis testing shows that the distribution of Zakat Funds has a significant influence on Economic Growth. Distribution of Zakat Funds also has a strong and direct relationship with Economic Growth, meaning that when the Distribution of Zakat Funds is large, the resulting Economic Growth will be large and vice versa. In this case, the distribution of zakat is good for every Muslim, as conveyed in Q.S. Al-Tawbah [9] : I03, which means: "Take zakat from some of their possessions, by which you cleanse and purify them, and pray for them. Verily, your prayer is the peace of their souls. And Allah is All-Hearing, All-Knowing."

The results of this study are in accordance with the theory explained by Ryandono (2008: 53) Zakat which is required in Islam has a function, one of which is as an instrument to encourage it can even be used to force someone to make their assets to be always productive. On the other hand the zakat will make the economy go round. With the rotation of assets in the economy, it will increase output (economic development and growth), employment, income and community welfare. In other words zakat can be used to control and encourage economic growth.

Based on the partial partial determination coefficient test the influence of the distribution of zakat funds to economic growth is $16.3 \%$, which means that economic growth is influenced by the distribution of zakat funds by I $6.3 \%$ while the remaining $83.7 \%$ is influenced by other factors not examined in this study. This study answers the phenomena that occur, in which phenomena that occurred in 20II, 2013, 2014, 2015 and 2017 the distribution of zakat funds increased while economic growth decreased. This is contrary to the theory expressed by experts when the distribution of zakat funds increases, economic growth also increases. The results of this study are consistent with the results of previous studies conducted by Rachmasari Anggraini (2018) ZIS has a positive effect on economic growth in Indonesia in the period 20II-20I5. This is because the higher distribution of ZIS funds indicates the higher level of economic growth in Indonesia. Research by (Komala, 2020) Zakat collection and distribution have positive impacts on equal distribution of wealth, cleanliness of wealth, economic growth, provision of educational facilities to needy students, and delivery of good health facilities in Indonesia. 


\section{E. CONCLUSION}

Based on the results of research and discussion regarding the distribution of zakat funds and local taxes on economic growth, then at the end of this study, the authors draw conclusions as follows: I) Distribution of secret funds affect economic growth. Where when the distribution of zakat funds increases, economic growth will increase and if the distribution of zakat funds decreases, economic growth will also decrease. 2) Local taxes affect economic growth. Where when local tax increase, economic growth will increase and if local taxes decrease, economic growth will also decline.

In order of the distribution of zakat funds can affect economic growth optimally, it should be done by improving the management of zakat funds starting from collection, utilization and distribution. Where the collection of zakat funds must be increased so that it will have an impact on the amount of zakat fund distribution. Increase the collection of zakat funds by coordinating programs that make it easier for people to pay zakat. For example, applying zakat payroll in a company. Advances in the usage and distribution of zakat funds can be increased by increasing distribution in the business capital granting program and monitoring of mustahiq that have been given zakat funds as business capital. And then that the secret funds provided can develop, and can affect economic growth. Local taxes can affect economic grows optimally, thus it must be increased again in terms of local tax revenue itself. Local tax revenue can be increased by more active procurement of tax information dissemination, technology improvement in tax reporting and payment. As has been enforced in the motor vehicle tax with e-Samsat, it should as well be given to other local taxes so that people find it easy to pay taxes.. 


\section{REFERENCES}

Abdul Halim, I. R. B. dan A. D. (2016). Perpajakan, Edisi 2. Jakarta: Salemba Empat.

Adel Sarea. (2012). Zakat as a Benchmark to Evaluate Economic Growth: An Alternative Approach. International Journal of Business and Social Science. Vol. 3 No. I8 [Special Issue - September 2012.

Arfah Habib Saragih. (2018). Pengatuh Penerimaan Pajak Terhadap Pertumbuhan Ekonomi. (2018), Jurnal Sikap. (Vol 3, No I, 20I8:17-27).

Arif Orçun Söylemez. (2017). Volatılity Spıllovers from The Internatıonal Capital Inflows to Economic Growth in Turkey. International Business and Accounting Research Journal. Volume I, Issue I, February 20I7, I8-25.

Ayu Yudiawati. (2013). Pengaruh Penagihan Pajak terhadap Penerimaan Pajak dan Implikasinya Terhadap Pertumbuhan Ekonomi. Skripsi: Universitas Komputer Indonesia.

B. Gashi, G. Asllani, L. B. (2018). The Effect of Tax Structure in Economic Growth. International Journal of Economics and Business Administration Volume VI, Issue 2. 56-67.

Beik, I. S. (2016). Islamisasi Ilmu Ekonomi. Jurnal Ekonomi Islam. (Vol 7, No 2, 2016:183-204).

Danang Sunyoto. (2016). Metodologi Penelitian Akuntansi. Bandung: PT Refika. Defia Riski Anggarini. (2018). Pengaruh Pendapatan Daerah dan Pajak Daerah terhadap Pertumbuhan Ekonomi Provinsi Lampung. Technobiz : International Journal Of Business. (Vol I, No I, 20I8:I-4).

Eko Suprayitno. (2018). Zakat And Sdgs: The Impact Of Zakat On Economic Growth, Consumption And Investment In Malaysia. dvances in Economics, Business and Management Research, volume IOI. Pp. 202-209.

Elleriz Aisha Khasandy \& Rudy Badrudin. (2019). The Influence of Zakat on Economic Growth and Welfare Society in Indonesia. JBE (Integrated Journal of Business and Economics) e-ISSN: 2549-3280/p-ISSN: 2549-5933. Pp 65-79.

Hesti Handiani. (2015). Analisis Pajak Daerah, Retribusi Daerah dan Tenaga Kerja Terhadap Pertumbuhan Ekonomi di Kabupaten Sragen Tahun I9952013.

Husaini Usman \& Purnomo Setiadi Akbar. (2017). Metode Penelitian Sosial. Jakarta : Bumi Aksara Group. 
Ioan Dan Morar. (2015). Taxation: Effects and influences. Procedia Economics and Finance $V o 132 . P p I 622-I 627$.

Iskandar Putong. (20I5). Economics, Edisi 5 Pengantar Mikro dan Makro. Jakarta: Mitra Wacana Media.

Joko Tri Haryanto. (2017). The Mapping of Economics Potency and Regional Independency in Java Island During The Fiscal Desentralization Era. Journal of Indonesian Applied Economics. Vol 7 No 2. Pp $201-227$.

Keumala Hayati and Indra Caniago. (20I I). Zakat Potential As A Means To Overcome Poverty (A Study In Lampung). Journal of Indonesian Economy and Business Volume 26, Number 2, 20II. Pp I87- 200.

Kharina Tambunan. (2016). Analisis Pengaruh Investasi, Operasi Moneter dan ZIS terhadap Pertumbuhan Ekonomi Indonesia. At-Tawassuth. (Vol I, No I, 20I6:73-94).

Komala, S. D. A. dan A. R. (2020). Akuntansi Syariah Peluang dan Tantangan. Bandung: Rekayasa Sains.

Mardani. (2016). Hukum Islam. Bandung : PT Citra Aditya Bakti.

Patmawati Ibrahim, Mazliana Muridan, M. A. and A. I. M. J. (2020). Revisiting Zakat Distribution on Income Inequality and Welfare: The Malaysia

Experience. Journal of Islamic Economics. Volume 4 Issue I, Pp. I46-I6I.

Petar Chobanov. (2019). Some Issues Confroting Bulgarian Economy. Finance, Accounting and Business Analysis. Volume I Issue I, 2019.

Rachmasari Anggraini. (2016). Analisis Pengaruh Dana Zakat, Infak Shodaqoh (ZIS) di Badan Amil Zakat Nasional (BAZNAS) dan Inflasi Terhadap Pertumbuhan Ekonomi di Indonesia pada Periode 20I I-2015. Skripsi: Universitas Airlangga.

Rahmad, T Zulham, C. S. (2019). The Analysis of Local Revenues and The Affecting Factors in The Implementation of Regional Autonomy in Aceh Province. Jurnal Ekonomi dan Kebijakan Publik Indonesia. Vol 6 No I Pp. 86-IO3.

Roshaiza Taha, Loganathan, N. and S. R. N. C. (2019). The Effect of Economic Growth on Taxation Revenue: The Case of a Newly Industrialized Country. International Review of Business Research Papers Vol. 7. No. I. Pp. 319 329.

Sapiudinn Shidiq. (2016). Fikih Kontemporer. Jakarta : Prenadamedia Group. Serhat Yüksel. (2017). The Impacts of Research and Development Expenses on Export and Economic Growth. International Business and Accounting 
Economic Growth : The Impact of Zakat Funds and Tax on Business Capital

Sri Dewi Anggadini ${ }^{1}$, Surtikanti, Surtikanti ${ }^{2}$, Faez M. Hassan ${ }^{3}$

Research Journal. Volume I, Issue I, Februaty 20I7, I-8.

Sri Dewi Anggadini dan Adeh Ratna Komala. (2017). Akuntansi Syariah.

Bandung: Rekayasa Sains.

Sugiyono. (2017). Metode Penelitian Kuantitatif, Kualitatif, dan R\&D. Bandung: Alfabeta, $C V$.

Ummu Salma Al Azizah and Muhammad Choirin. (2018). Financial Innovation on Zakat Distribution and Economic Growth. International Conference of Zakat 2018 Proceedings. Pp $3 I-42$.

Waluyo. (20I4). Perpajakan Indonesia, Edisi II. Jakarta : Salemba Empat. 